\title{
A SMALL COLLECTION OF HEPATICS FROM OREGON AND CALIFORNIA (WESTERN NORTH AMERICA)
}

\section{НЕБОЛЬШАЯ КОЛЛЕКЦИЯ ПЕЧЕНОЧНИКОВ ИЗ ОРЕГОНА И КАЛИФОРНИИ (ЗАПАД СЕВЕРНОЙ АМЕРИКИ)}

\author{
VADIM A. BAKALIN ${ }^{1,2}$ \\ ВАДИМ А. БАКАЛИН ${ }^{1,2}$
}

\begin{abstract}
Identification of small hepatic collection of 112 specimens, collected by M. Ignaotvin California and Oregon, reveals 47 species (46 liverworts, 1 hornwort), including 9 species new to California: Cephaloziella varians, Chiloscyphus rivularis, Lophozia guttulata, Lophozia savicziae, Marchantia alpestris, Plagiochila ovalifolia, Scapania obscura, Solenostoma pseudopyriflorum, and Scapania parvifolia var. grandiretis. Annotated list include comments on ecology and, in some cases, species morphology. The key for Scapania sect. Ciliatae (S. ciliata, S. hirosakiensis, S. americana, S. hollandiae) distributed in North Pacific is provided.
\end{abstract}

Резюме

Определение небольшой коллекции печеночников (112 образцов), собранных М.Игнатовым в штатах Калифорния и Орегон, позволило выявить 47 видов (46 печеночников и 1 антоцерот), в том числе 9 новых для штата Калифорния: Cephaloziella varians, Chiloscyphus rivularis, Lophozia guttulata, Lophozia savicziae, Marchantia alpestris, Plagiochila ovalifolia, Scapania obscura, Solenostoma pseudopyriflorum, and Scapania parvifolia var. grandiretis. Приводится аннотированный список, включающий комментарии по экологии и, в некоторых случаях, морфологии видов. Составлен ключ для определения видов Scapania sect. Ciliatae (S. ciliata, S. hirosakiensis, S. americana, S. hollandiae) распространенных в Северной Пацифике.

KEYWORDS: California, Hepaticae, Oregon, phytogeography, the Russian Far East, western North America.

\section{INTRODUCTION}

The investigations of liverworts and hornworts in Oregon and California have a long history and covers over one hundred and fifty years. The first data on hepatic in these states were apparently published by Sullivant (1849), including some species described as new to science, e.g. Frullania nisquallensis from Oregon. Some early records were also provided by Austin (1869) and Underwood (1888). The first checklist of Oregon hepatics was published by Haynes (1909), who enumerated 19 species mostly collected in Portland surroundings. The first data on Californian hepatics were summarized by Howe (1899) in the widely known "The Hepaticae and Anthocerotae of California", where data on distribution of 86 species are provided. Since then a lot of species were recorded for both states in floristic (Clark \& Frye, 1934, etc.), ecological (Wagner et al., 2000, etc.), and taxonomical (Hong, 1989; Bakalin, 2012, etc.) papers. The available data were summarized for California by Doyle \& Stotler (2006) and include 135 species of He- paticae and 7 of Anthocerotae. The data on Oregon hepatics were not published recently. There are two partly out of dated summaries as "Liverworts of the Northwest" by Clark \& Frye (1928) and "Hepaticae and Anthocerotae of Western Oregon" by Sanborn (1929).

The present account based on the study of 112 specimens collected by M. Ignatov in 1989 in Oregon (Curry County) and northern California (Mono, Tuolumne, Shasta, Humboldt and Siskiyou Counties), covers elevations from 100 to $3100 \mathrm{~m}$. Despite the fact that only 46 liverworts and 1 hornwort are identified in the studied material, 9 taxa are newly recorded for California, and some new data on ecology and altitudinal range of a number of taxa are found.

\section{LIST OF SPECIES}

The nomenclature follows some novelties from the recently published Checklist of Liverworts of Russia (Konstantinova et al., 2009). After species names come distribution in counties within California (CA) and Oregon (OR), altitudinal range (basing on the studied spec-

\footnotetext{
1 - Botanical Garden-Institute FEB RAS, Makovskogo Street, 142, Vladivostok, 690024, Russia - Россия, 690024 Владивосток, ул. Маковского, 142, Ботанический сад-институт ДВО РАН

2 - Institute of Biology and Soil Science FEB RAS, Stoletiya Vladivostoka Avenue, 159, Vladivostok, 690022, Russia - Россия, 690022, Владивосток, пр. Столетия Владивостока, 159, Биолого-почвенный институт ДВО РАН; e-mail: v_bak@list.ru
} 
imens), habitat description and a list of associated taxa. Taxonomical or other comments are given for some species. The voucher specimens are kept in MHA and VBGI (duplicates). Species new to California are marked by asterisk.

Aneura pinguis (L.) Dumort. - CA: Shasta Co. - 1950 $\mathrm{m}$ - wet slope to creek.

Anthelia juratzkana (Limpr.) Trev. - CA: Mono Co. - $3100 \mathrm{~m}$ - wet creek side - with Cephalozia bicuspidata, Lophozia cf. savicziae.

Blepharostoma trichophyllum (L.) Dumort. var. trichophyllum - CA: Tuolumne Co., OR: Curry Co. - 900$2750 \mathrm{~m}$ - wet area near waterfall; dry trunk near creek; in pure mats or with Schistochilopsis incisa.

Calypogeia integristipula Steph. - CA: Mono Co $3100 \mathrm{~m}$ - rather dry outcrops near creek - with Cephalozia bicuspidata.

C. muelleriana (Schiffn.) Müll.Frib. - CA: Mono Co. - $3100 \mathrm{~m}$ - under willow thickets near stream - with Cephalozia bicuspidata, Cephaloziella divaricata, Lophozia sudetica, Scapania irrigua.

C. neogaea (R.M. Schust.) Bakalin - CA: Humboldt Co., Siskiyou Co. $-100-1500 \mathrm{~m}$ - pit wall on prairie with scattered trees of Quercus garryana Douglas ex Hook.; soil banks, rotten log, hard dry loam in redwood forest - with Cephalozia cf. lunulifolia, Cephaloziella turneri, Lepidozia reptans, Scapania bolanderi, Solenostoma rubrum.

Cephalozia bicuspidata (L.) Dumort. - CA: Humboldt Co., Mono Co., Tuolumne Co. - ant., arch. - 100$3100 \mathrm{~m}$ - ponds in meadows in high altitude, banks of streams, decaying wood of Pseudotsuga - in pure mats or with Anthelia juratzkana, Calypogeia integristipula, C. muelleriana, Lophozia savicziae, Lophozia sudetica, Plectocolea hyalina, Riccardia palmata.

C. lunulifolia (Dumort.) Dumort. - CA: Humboldt Co. - ant., arch., per. - 350-600 m - pit wall in prairie with scattered trees of Quercus garryana, decaying log in virgin redwood - Calypogeia neogaea, Cephalozia bicuspidata, Cephaloziella turneri, Lepidozia reptans, Scapania bolanderi, Solenostoma rubrum. - One specimen represents a peculiar form superficially similar to Cephalozia catenulata (Huebener) Lindb., with which $C$. lunulifolia was confused before in California (cf. Doyle \& Stotler, 2006). The plants have uncharacteristically narrow cells in the leaf base (ca. $15-19 \mathrm{mcm}$ wide versus $25-30 \mathrm{mcm}$ in typical $C$. lunulifolia), but in other features, such as dentate perianth mouth and larger dorsal epidermis cells (30$36 \mathrm{mcm}$ wide), they confirm C. lunulifolia.

Cephaloziella divaricata (Sm.) Schiffn. - CA: Mono Co. $-3100 \mathrm{~m}$ - soil under willow near lake - with Calypogeia muelleriana, Scapania irrigua.

C. turneri (Hook.) Müll. Frib. - CA: Humboldt Co. per. $-100-600 \mathrm{~m}-$ pit wall in prairie with scattered trees of Quercus garryana; vertical roadside bank in redwood forests - with Calypogeia neogaea, Cephalozia cf. lunu- lifolia, Scapania bolanderi, Solenostoma rubrum.

${ }^{*}$ C. varians (Gottsche) Steph. - CA: Mono Co. -3100 $\mathrm{m}-$ pond in alpine meadow near lake.

*Chiloscyphus rivularis (Schrad.) Hazsl. - CA: Humboldt Co. $-100 \mathrm{~m}$ - rocks in water in virgin redwood.

Conocephalum conicum (L.) Und. - CA: Humboldt Co. $-100 \mathrm{~m}$ - wet roadside in redwood forest - in pure mats or with Pellia neesiana.

Frullania bolanderi Aust. - CA: Humboldt Co. -60 m - Alnus trunk near stream - with Frullania franciscana.

F. californica (Austin) A.W. Evans - CA: Humboldt Co. - arch. $-850 \mathrm{~m}-$ rock outcrops $-F$. californica treated as an endemic species of the Pacific North-West (recorded for British Columbia, Washington, Oregon, California), is very similar by appearance to East-Asian $F$. diversitexta. The comparison of available specimens as well as descriptions of the both species revealed minor differences, such as 1) sporadical presence of apiculate leaves in $F$. californica vs. always rounded in $F$. $d i$ versitexta, 2) more deeply lobed underleaves (up to $1 /$ 2 in Doyle \& Stotler, 2006 and 1/3 in Hong, 1989) vs. underleaves lobed up to $1 / 5-1 / 4$ of the length, 3) smooth perianth in F. californica vs. tuberculate in $F$. diversitex$t a$. Two of the former features are quantitative, and the latter is inconstant in $F$. diversitexta.

F. franciscana M.A. Howe - CA: Humboldt Co. ant., per. $-60-600 \mathrm{~m}-$ oak trunks in prairie with scattered trees of Quercus garryana; on Alnus rubra, Lithocarpus and Rhamnus trunks, Vaccinium ovatum branches near streams in redwood forests - in pure mats or with Frullania bolanderi, Porella navicularis. - F francisca$n a$, a more or less frequent epiphytic or (rarely) epilithic taxon of Boreal and Temperate North America, is malleable in morphology. In our material, we frequently found forms with acuminate-apiculate lobe apex, described also by Hattori (1972), Hong (1989) and Doyle \& Stotler (2006). These forms are not differentiable in appearance from East Asian F. appendiculata Steph. Minor differences found in literature (poorly developed stylus in $F$. franciscana vs. large in $F$. appendiculata; gradually narrowed non-appendiculate, flat underleaves vs. appendiculate underleaves with recurved margin, etc., cf. Hattori, 1972) are sometimes difficult to apply. Both ecological conditions and altitude are similar for this pair. In this case we probably have in hand the vicarious taxa of intraspecific rank.

F. nisquallensis Sull. - CA: Humboldt Co. - ant., per., spor. $-100-850 \mathrm{~m}$ - rocks outcrops in virgin redwood and prairie with scattered Quercus garryana - in pure mats or with Porella bolanderi, P. navicularis. - F. nisquallensis was originally described "on the bark of trees" (Sullivant, 1849: 175) and was treated as the species occurring mostly on tree trunks, rarely on logs and rocks within low elevations of temperate or (more rarely) boreal zones. Hattori (1972) first recorded it in the 
Arctic zone basing on the study of Steere's collections (referred by Steere (1965) as F. tamarisci (L.) Dumort. s.l.), with a note: "the plants are large" (Hattori, 1972: 239). Later $F$. nisquallensis was found in many localities in Russian Arctic or in the respective alpine belt southward (Schljakov, 1982; Bakalin, 2010) in the Russian Far East. In addition to an unstable character "large size", it always occurs in rather hygrophytic and basic conditions in tundras and is conspicuously vinaceous-black in color, but never occurs in forested areas. The question arises: if it is really the same species as the taxon so common in California and Oregon, why does not it occur in the same habitats? Obviously, further study is required to evaluate the relevance of the abovementioned "Arctic phase".

Lepidozia reptans (L.) Dumort. - CA: Humboldt Co. $-100 \mathrm{~m}$ - rotten log and trunks in virgin redwood - with Calypogeia neogaea, Cephalozia bicuspidata, C. lипиlifolia.

*Lophozia savicziae Schljak. - CA: Mono Co. -3100 m - creek wall - with Anthelia juratzkana, Cephalozia bicuspidata.

L. sudetica (Huebener) Grolle - CA: Mono Co. gemm. - $3100 \mathrm{~m}$ - cliffs near the creek - with Calypogeia muelleriana, Cephalozia bicuspidata.

*L. guttulata (Lindb. et Arnell) A. Evans - CA: Siskiyou Co. - gemm. - $1500 \mathrm{~m}$ - side of boulder near creek.

L. ventricosa (Dicks.) Dumort. var. ventricosa-CA: Mono Co. - gemm., per. - $3100 \mathrm{~m}$ - soil outcrops along road in Pinus forest; soil bank of pool; soil outcrops near waterfall - in pure mats or with Scapania irrigua.

*Marchantia alpestris (Nees) Burgeff - CA: Mono Co., Shasta Co. - gemm. - 1950-3100 m - pool bank; among sedges on the lake shore.

M. latifolia Gray - CA: Humboldt Co. $-100 \mathrm{~m}-$ creek bank in virgin redwood.

Marsupella sphacelata (Gieseke ex Lindenb.) Dumort. - CA: Shasta Co. - $2520 \mathrm{~m}$ - wet snowbed meadow near stream.

Pellia endiviifolia (Dicks.) Dumort. - CA: Humboldt Co. $-60 \mathrm{~m}$ - bank of stream.

P. neesiana (Gott.) Limpr. - CA: Humboldt Co. $100 \mathrm{~m}$ - bank of stream in virgin redwood - with Conocephalum conicum.

Phaeoceros carolinianus (Michx.) Prosk. - CA: Humboldt Co. - spor. $-350 \mathrm{~m}$ - clay outcrops along the creek in virgin redwood.

*Plagiochila ovalifolia Mitt. - OR: Curry Co. - 900 $\mathrm{m}$ - boulder - with Porella roellii - The relationships of P. ovalifolia and P. porelloides are very obscure. Two taxa were regarded as the varieties of one species by Inoue (1958), but were maintained as discrete species by So (2001). The differentiation features between the two taxa are limited by 1) dentate to denticulate leaf margin in P. ovalifolia vs. dentate to smooth margin in P. porelloides, 2) 2-3 layers of cortex in the former vs. 3-5 in the latter, 3) commonly ciliate perianth mouth in $P$. ovlaifo- lia vs. commonly dentate in $P$. porelloides (but not constantly as written by So, 2001; P. porelloides sometimes has ciliate perianth mouth too, cf. Schuster, 1980). In our judgment, these two taxa need further study.

P. porelloides (Torrey ex Nees) Lindenb. - CA: Humboldt Co. $-850 \mathrm{~m}$ - rock outcrops with Quercus garrya$n a$ on $\mathrm{N}$ - facing slope; soil bank along road.

Plectocolea hyalina (Lyell) Mitt. - CA: Tuolumne Co. $-2750 \mathrm{~m}$ - creek in meadow - with Cephalozia bicuspidata.

Porella bolanderi (Austin) Pearson - CA: Humboldt Co. $-100 \mathrm{~m}-$ Acer trunk in virgin redwood - with Frullania nisqualensis.

P. cordeana (Huebener) H. Buch - CA: Siskiyou Co. OR: Curry Co. $-1100-1500 \mathrm{~m}-$ Populus trunks in deep ravine; wet big boulder near the stream.

P. navicularis (Lehm. et Lindenb.) Lindenb. - CA: Humboldt Co., OR: Curry Co. - ant., per., spor. -60 $1100 \mathrm{~m}$ - rock outcrops in prairie with scattered trees of Quercus garryana, redwoods; Alnus rubra, Acer and Quercus trunks, Vaccinium ovatum branches - in pure mats or with Frullania nisqualensis.

P. roellii Steph. - OR: Curry Co. $-900 \mathrm{~m}$ - boulder with Plagiochila ovalifolia.

Radula bolanderi Gottsche - OR: Curry Co. $-900 \mathrm{~m}$ - Quercus trunk in conifer forest - with Porella navicularis.

R. complanata (L.) Dumort. - CA: Humboldt Co., Siskiyou Co. - ant., per., spor., gemm. $-60 \mathrm{~m}-$ Rhamnus trunk; rocks under Alnus aside a stream - the phenotypes of $R$. complanata in Californian collections are rather similar to eastern-Asian ones and strikingly contrast with European and Siberian. The main distinctive characters include 1) rare presence of the gemmae (completely absent in most studied specimens both in Eastern Asia (cf. Yamada, 1977) and California) versus almost obligate gemmae presence in other Eurasian provinces, 2) relatively longer perianth (ca. 2.2-2.6 as long as wide versus $1.5-2.0), 3$ ) commonly distant (not contiguous) leaves versus mostly imbricate. The listed differences show the need of additional comparative studies of the both phenotypes to evaluate their rank.

Riccardia chamaedryfolia (With.) Grolle - CA: Mono Co. $-3100 \mathrm{~m}-$ area near lake.

R. multifida (L.) Gray ssp. multifida - CA: Humboldt Co., OR: Curry Co. - ant., arch., gemm. - 350-900 m clay and rocks outcrops along the creek in virgin redwood.

R. palmata (Hedw.) Carruth. - CA: Humboldt Co. $100 \mathrm{~m}$ - wet rotten log in secondary stand with Sambucus and virgin redwoods - in pure mats or with Cephalozia bicuspidata.

Scapania americana Müll. Frib. - CA: Humboldt Co., OR: Curry Co. - gemm. $-850-1300 \mathrm{~m}-$ rocks outcrops, soil among rocks.

The species shows the close relation to some other 
taxa that have been repeatedly noted: (1) Doyle \& Stotler (2006) stressed the similarity of $S$. americana with $S$. bolanderi and gave differentiation features between two species. Authors also listed, that (1.c.: 181): [Scapania bolanderi has] "basal portion of dorsal lobe ciliate, the cilia usually branched, antleroid (vs. basal portion of lobe entire to short dentate, not ciliate or antleroid)". The same was observed by Amakawa (1967) in the review of North Pacific Scapania sect. Gracilidae. Nevertheless we found in our specimens of $S$. americana, some plants have antleroid branched teeth in the basal portions of dorsal lobe. (2) T. Amakawa (1967) and Potemkin (2001) emphasized close relationships of $S$. americana with $S$. ciliata Sande Lac. Two species have obvious differences in marginal teeth and gemmae characteristics, but, as we found, not in cuticle (as it was written by the cited authors), which is frequently coarsely papillose in the both species. (3) In our experience it is even more troublesome to differentiate $S$. americana from Temperate East-Asian S. hirosakiensis Steph. ex Müll. Frib. In the comments to the original description of $S$. hirosakiensis, Müller (1905) stated close affinity of this taxon to $S$. evansii Bryhn (=S. undulata (L.) Dumort.) and placed it to "Gruppe Dentata-Undulata". Afterward S. hirosakiensis was regarded as a distinct variety within $S$. parvitexta Steph. (Hattori, 1950), or as complete synonym of the latter and was placed to sect. Stephania Amakawa et S. Hatt. (Amakawa \& Hattori, 1954). The taxon was reestablished in species rank by Potemkin (2001), who placed it to sect. Ciliatae Grolle.

Since Amakawa's (1967) key to the species of this group in the North Pacific is partly out of date, we present here the identification key to the species of Scapania sect. Ciliatae (within limits determined by Potemkin (2001), but with an exception of S. spitzbergensis (Lindb.) Müll. Frib., which is rather a member of sect. Undulatae (Choi et al., 2012)) distributed around the northern Pacific. Thereby the key includes here S. ciliata, S. hirosakiensis, S. americana and S. hollandiae W.S. Hong (the latter is poorly known, cf. Potemkin, 2001). The general distribution is provided in square brackets.

1. Ventral leaf lobes entire to denticulate, barely decurrent; perianth mouth dentate; plants soft [Western North America: British Columbia, Washington, Wyoming] ............................................ S. hollandiae

1. Ventral leaf lobes sharply dentate, evidently decurrent for ca. 1/2-3/2 of stem width; perianth mouth lobulate-ciliate; plants rather rigid.

2. Marginal leaf lobes teeth 1-2-celled, with the last cell 2.5-4 times as long as wide; apex of the lobes rather rounded [Temperate East Asia: Japan, Korea, Russian Primorsky Territory] ............................ S. ciliata

2. Marginal leaf lobes teeth 3-4-celled, with the last cell 1.5-2.0 as long as wide; apex of the lobes obtuse to acute
3. Plants mostly yellowish to brownish and brown; gemmae more or less common, 2-celled, yellowish brown to vinaceous-red in color; mostly on rocky substrata [Western USA: Alaska, British Columbia, Washington, Oregon, California] S. americana

3. Plants mostly green to greenish; gemmae rare, when present 1-celled, green; mostly on decaying wood [Temperate East Asia: Japan, Russian Kurils Islands] S. hirosakiensis

S. bolanderi Austin - CA: Humboldt Co. - per. 100-600 m-decaying wood, base of trunks and clay roadside in virgin redwoods - with Calypogeia neogaea, Cephalozia bicuspidata, C. cf. catenulata, C. lunulifolia, Cephaloziella turneri.

S. irrigua (Nees) Nees - CA: Mono Co., Tuolumne Co. $-2750-3100 \mathrm{~m}-$ soil banks of lakes and streams; cliffs near waterfalls - with Calypogeia muelleriana, Cephaloziella divaricata, Lophozia ventricosa.

*S. obscura (Arnell \& C.E.O. Jensen) Schiffner-CA: Mono Co. $-3100 \mathrm{~m}-$ creek bank.

*S. parvifolia Warnst. var. grandiretis Schljakov CA: Tuolumne Co. $-2750 \mathrm{~m}$ - soil outcrops near lake. Neither $S$. parvifolia, nor its var. grandiretis were recorded for California. However, S. parvifolia sometimes being considered as synonymous with $S$. scandica (Arnell et $\mathrm{H}$. Buch) Macvicar, which is recorded for California by Doyle and Stotler (2006).

S. undulata (L.) Dumort. - CA: Humboldt Co. -350 $\mathrm{m}$ - temporarily flooded rocks in virgin redwood.

Schistochilopsis incisa (Schrad.) Konst. - OR: Curry Co. - gemm. $-900 \mathrm{~m}-$ dry trunk above creek - with Blepharostoma trichophyllum.

*Solenostoma pseudopyriflorum Bakalin et Vilnet CA: Mono Co. - ant., per. - $3100 \mathrm{~m}$ - lake shore - this species was described from North Temperate Asia (Bakalin \& Vilnet, 2009), being more or less similar to $S$. sphaerocarpum (Hook.) Steph. and S. confertissimum (Nees) Schljakov in monoicous inflorescence and to $S$. pyriflorum Steph. in general appearance. The species differs from $S$. sphaerocarpum in absence of sepia-brown coloration (in exposed sites it tends to develop purple, no sepia pigmentation) and leaves sheathing the stem in the base. It differs from $S$. confertissimum in absence of rhizogenous cells around leaf lamina and differs from the both aforementioned in bistratose perianth-wall in its lower half. S. pseudopyriflorum differs from S. pyriflorum in paroicous inflorescence as well as more rigid structure of plants with more contiguous leaves.

S. rubrum (Gottsche) R.M. Schust. - CA: Humboldt Co., Shasta Co. - 600-2370 m - bank of small stream; pit wall in prairie with scattered trees of Quercus garryana - in pure mats or with Calypogeia neogaea, Cephalozia cf. lunulifolia, Cephaloziella turneri.

\section{ACKNOWLEDGEMENTS}

The author is indebted to M. Ignatov, who made available to study his specimens, collected in a trip to Califor- 
nia organized and sponsored by Prof. R.W. Becking and to Oregon arranged by Dr. D.H. Norris. This study was partially supported by Russian Foundation for Basic Research (grants 10-04-00050-a, 12-04-91150-ГФЕН-a).

\section{LITERATURE CITED}

AMAKAWA, T. \& S. HATTORI 1954. A revision of the Japanese species of Scapaniaceae. II. - J. Hattori Bot. Lab. 12: 91-112.

AMAKAWA, T. 1967. Scapania sect. Gracilidae of the Areas around the North Pacific Ocean. - J. Hattori Bot. Lab. 30: 315-327.

AUSTIN, C.F. 1869. Characters of some new Hepaticae (mostly North American), together with notes on a few imperfectly described species. - Proc. Acad. Nat. Sci. Philadelphia 21: 218-234.

BAKALIN, V.A. 2012 Solenostoma fusiforme: an addition to the North American liverwort flora and a review of the genus Solenostoma in North America, North of Mexico. - Polish Bot. Journ. 57(1): 137143

BAKALIN, V.A. \& A.A. VILNET 2009. Two new species of Jungermanniaceae from Asiatic Russia. - Arctoa 18: 151-162.

CHOI, S.S., V.A. BAKALIN \& B.Y. SUN 2012. Scapania and Macrodiplophyllum in the Russian Far East. - Botanica Pacifica 1: 31-95.

CLARK, L. \& T.C. FRYE 1928. Liverworts of the Northwest. - Publicationd Puget Sound Biological Station 6: 1-194.

CLARK, L. \& T.C. FRYE 1934. Liverworts new to the northwestern states. - Bryologist 37(1): 1-2.

DOYLE, W.T. \& R.E. STOTLER 2006. Contributions toward a bryoflora of Californis III. Keys and annotated species catalogue for liverworts and hornworts. - Madrono 53(2): 89-197.

FULFORD, M. 1936 Some Hepaticae from Washington, Oregon and Idaho collected by Dr. Arthur Svihla. - Bryologist 39(5): 105-111.

HATTORI, S. 1950. Contribution as Floram Hepaticarum Yakushimensem, IV. - J. Hattori Bot. Lab. 4: 49-71. [In Japanese]

HATTORI, S. 1972. Frullania tamarisci-complex and the species concept. - J. Hattori Bot. Lab. 35: 202-251.

HAYNES, C.C. 1909. An enumeration of the Washington and Oregon Hepaticae collected by Mr. A.S. Foster, 1904-1909. - Bryologist 12(4): $65-71$
HONG, W.S. 1989. The genus Frullania in North America west of the Hundredth Meridian. - Bryologist 92(3): 363-367.

HOWE, M.A. 1899. The Hepaticae and Anthocerotae of California. Memoirs of the Torrey Botanical Club 7: 1-208.

INOUE, H. The family Plagiochilaceae of Japan and Formosa. I. - J. Hattori Bot. Lab. 19: 25-59.

KAMIMURA, M. 1961. A monograph of Japanese Frullaniaceae. - $J$. Hattori Bot. Lab. 24: 1-109.

KONSTANTINOVA, N.A., V.A. BAKALIN with contributions on regional floras from E.N. ANDREEVA, A.G. BEZGODOV, E.A. BOROVICHEV, M.V. DULIN, YU S. MAMONTOV. 2009. Checklist of liverworts (Marchantiophyta) of Russia. - Arctoa 18: 1-64.

MULLER, K. 1905. Monographie der Lebermoosgattung Scapania Dumort. - Nova Acta Abh. der Kaiserl. Leop-Carol. Deutschen Akademie der Naturforscher 83: 1-310.

[POTEMKIN, A.D.] ПОТЕМКИН, А.Д. 2001. Эволюция, филогения, классификация семейства Scapaniaceae (Hepaticae) - [Evolution, phylogeny and classification of Scapaniaceae family (Hepaticae)]. Санкт-Петербург [Saint-Petersburg], 338.

SANBORN, E.I. 1929. Hepaticae and Anthocerotae of Western Oregon. - University of Oregon Publication 1(1): 5-111.

SCHUSTER, R.M. 1980. The Hepaticae and Anthocerotae of North America. Vol. 4. - New York, Columbia University Press, 1334 pp.

SO, M.L. 2001. Plagiochila (Hepaticae, Plagiochilaceae) in China.-Systematic Botany Monographs 60: 1-214.

STEERE, W.C. 1965. The boreal bryophyte flora as affected by Quaternary glaciations. - In: Wright, H.E. \& D.G. Frey (eds.) The Quaternary of the United States. Princeton Univ. Press, 485-495.

SULLIVANT, W.S. 1849. Contributions to the Bryology and Hepaticology of North America. - Mem. Amer. Acad. Art and Science. n.s. 4: 169-176.

UNDERWOOD, L.M. 1888. Some undescribed Hepaticae from California. - Botanical Gazette 13(5): 112-114.

WAGNER, D.H., J.A. CHRISTY \& D.W. LARSON 2000. Deep-water Bryophytes from Waldo Lake, Oregon. - Lake and Reservoir Management 16(1): 91-99.

YAMADA, K. 1977. A revision of Asian taxa of Radula, Hepaticae. - J. Hattori Bot. Lab. 45: 201-322. 